\title{
URINARY EXCRETION OF UREA, URIC ACID AND AMMONIA IN PYGOSCELLIDAE PENGUINS*
}

\section{EDSON RODRIGUES $^{1 * *}$; CLEONI SANTOS CARVALHO ${ }^{2}$ LIÍGIA MARIA SALVO $^{2}$; $_{\text {METRY BACILA }}^{3}$}

Brazilian Antarctic Station Commander Ferraz, King George Island, South Shetlands. ${ }^{1}$ Faculdade de Ciências Farmacêuticas, Universidade São Francisco, Bragança Paulista, SP, Brazil. ${ }^{2}$ Laboratório de Piscicultura, Universidade Federal do Paraná, Curitiba PR, Brazil. ${ }^{3}$ Centro de Ciências Biológicas e da Saúde, Pontifícia Universidade Católica do Paraná - PUC-PR.

\begin{abstract}
In order to carry out further studies on the nitrogen metabolism in Antarctic birds, a study has been carried out on the levels of nitrogenous excretory products in the urine of 29 Pygoscellidae penguins: Pygoscellis antarctica, $\mathrm{n}=2 ;$. adeliae, $\mathrm{n}=16$, and P. papua, $\mathrm{n}=11$. According to the results of the present experiment, it has been found that in spite of the fact that those birds excrete uric acid as the main final product of the nitrogen metabolism, the high levels of blood urea displayed by them as well as the fact that they possess an hepatic arginase of high affinity, comparable to the liver arginase from laboratory mammals, may be considered as evidences of the ureogenic activity displayed by them.
\end{abstract}

RESUMO - Foi conduzido um estudo sobre os níveis de excreção urinária de produtos finais do metabolismo nitrogenado em 29 pingüins Pygoscellidae: Pygoscellis antarctica, $\mathrm{n}=2 ;$. adeliae, $\mathrm{n}=16$, e $P$. papua, $\mathrm{n}=11$. De acordo com os resultados obtidos, verificou-se que apesar dessas aves excretarem ácido úrico como principal produto final do seu metabolismo nitrogenado, os altos níveis de uréia sangüínea que exibem bem como o fato de possuírem uma arginase hepática de alta afinidade, comparável com aquela do fígado de mamíferos utilizados como animais de laboratório, podem ser considerados como evidências da atividade ureogênica exibida por elas.

\section{Introduction}

Since the now classical and historical work carried out by CLEMENTI (1946) on the nitrogen metabolism in vertebrates (for a review see RODRIGUES et al, 1996) the assumption that birds are typical uricotelic animals became an important issue of discussion and research. In another historical contribution in regard to comparative aspects of birds metabolism, particularly in regard to the nitrogenous excretory products of chick embryos at different stages of development, NEEDHAM (1938) showed that at the very beginning of development, the chick produces ammonia like an aquatic animal but up to the $9^{\text {th }}$ day of development the chick switches off in favour of urea, behaving, this way, for a time, as an amphibian animal. Finally, as BALDWIN (1947) states, the chick appears in its true colours as a truly terrestrial uricotelic organism developing inside a cleidoic egg.

In spite of being considered uricotelic in regard to the nitrogen excretion, birds display blood urea levels that change as a function of the feeding habits and of species. Values as high as $36 \mathrm{mg} / \mathrm{dL}$ of blood serum urea were found by FERRER et al. (1987) in birds of pray. In Antarctic birds, ROSA et al. (1993) found

\footnotetext{
*With a grant-in-aid from the Brazilian Antarctic Program (Brazilian Antarctic Program, Laboratório de Piscicultura, Universidade Federal do Paraná, Curitiba, PR, Brasil) PROANTAR-CNPq. **To whom all correspondence should be sent: Prof. Edson Rodrigues - Universidade São Francisco, Faculdade de Ciências Farmacêuticas, Av. São Francisco de Assis, 218, Bragança Paulista, SP, Brazil, CEP 12.900-00.
}

still higher values for blood serum urea in the skua Chataracta maccormicki (54.8 $\mathrm{mg} / \mathrm{dL})$ and lower values for the penguins Pygoscellis antarctica (13.8 $\mathrm{mg} / \mathrm{dL})$ and Pygoscellis papua $(6.3 \mathrm{mg} / \mathrm{dL})$.

On the other hand, RODRIGUES et al. (1998) carried out studies on the nitrogen metabolism performed by Antarctic birds - penguins and skuas. Information has then being given on the values of blood serum urea, uric acid and creatinine in Pygoscellidae penguins. Furthermore, it has been found that besides displaying a high content of blood urea these birds also possess a liver arginase of high affinity towards its substrate, comparable to the one shown by typical ureotelic laboratory mammals. In order to further study this problem a research was undertaken aiming to analyze the levels of nitrogenous excretory products in the urine of Pygoscellidae penguins.

\section{Materials and Methods}

A total of 29 adult Pygoscellidae penguins (Pygoscellis antarctica, $\mathrm{n}=2 ; P$. adeliae, $\mathrm{n}=16$; and $P$. papua, $\mathrm{n}=11$ ) were used in this experiment. Two chinstrap penguins were captured wondering in front of the Brazilian Antarctic Station, while the lot of 16 adelies and 11 gentoos were captured at the Arctowsky rookery. Upon the urine sampling, the birds were immediately set free. The urine was excreted by the bird as a reflex of the stressing situation underwent by them. The urine was then collected by means of an adequate glassware. 
Dilutions of urine samples has been carried out with a chilled $0.2 \%$ sodium carbonate solution according to the methodology of McNABB and McNABB (1975). Urea was assayed by the urease splitting method followed by indophenol colorimetric assay of the released ammonia according to BERGMEYER (1985); uric acid was assayed by the method of CARAWAY (1955); and ammonia by the colorimetric indophenol method of CHANEY and MARBACH (1962).

\section{Results and Discussion}

Table 1 shows values of nitrogenous excretory compounds, as $\mathrm{mM} / \mathrm{L}$ assayed in the urine of Pygoscellidae penguins $P$. adeliae, $P$. antarctica and $P$. papua. On the other hand, Fig. 1-3 show a comparative study carried out between the levels of urea and uric acid found in the urine and in the blood of $P$. antarctica, $P$. adeliae and $P$. papua. The blood values were according to RODRIGUES et al. (1998).

The systematic study of uric acid and urea biogenesis as well as of the levels of enzymes of the urea biosynthesis allows to consider the phylogenetic aspects of the nitrogen metabolism in birds and mammals. KATUNUMA et al. (1970) found out that a hyperproteic diet induces the raise in the levels of glutamine synthase and of glutamine-PRPPamidotransferase in domestic birds' liver, as well as the raise of the levels of glutaminase and the enzymes of the urea cycle in rat's liver. However, birds under hyperproteic diet showed a very neat raise in blood uric acid which was smaller in the case of urea. On the contrary, rats under the same diet experienced a significant raise in blood urea but not in uric acid which raise was smaller.

Table 1. Levels of urine excreting urea, uric acid and ammonia by native Pygoscellidae penguin.

\begin{tabular}{l|c|c|c}
\hline Penguin & Urea $(\mathrm{mMol} / \mathrm{L})$ & Uric Acid $(\mathrm{mMol} / \mathrm{L})$ & Ammonia $(\mathrm{mMol} / \mathrm{L})$ \\
\hline P. papua & $165.7 \pm 12.0$ & $959,4 \pm 63.4$ & $350,4 \pm 17.0$ \\
P. adeliae & $110.5 \pm 9.4$ & $984,7 \pm 93.8$ & $260,6 \pm 30.4$ \\
P.antarctica & $351.8 \pm 64.6$ & $597,6 \pm 52.2$ & $383,8 \pm 87.5$ \\
\hline
\end{tabular}

Values expressed as mean $\pm \mathrm{SE}$

Studies on the blood levels of urea and uric acid carried out by RODRIGUES et al. (1996) in Antarctic birds under 24 hours of fasting or in native conditions, found out higher levels of blood urea than the ones displayed by uric acid (Fig. 1-3). It was also found out that the liver arginase from these birds possess a high affinity (low $\mathrm{Km}$ ) for arginine very near to that one displayed by arginase from mammals.

\section{Pygoscellis antarctica}

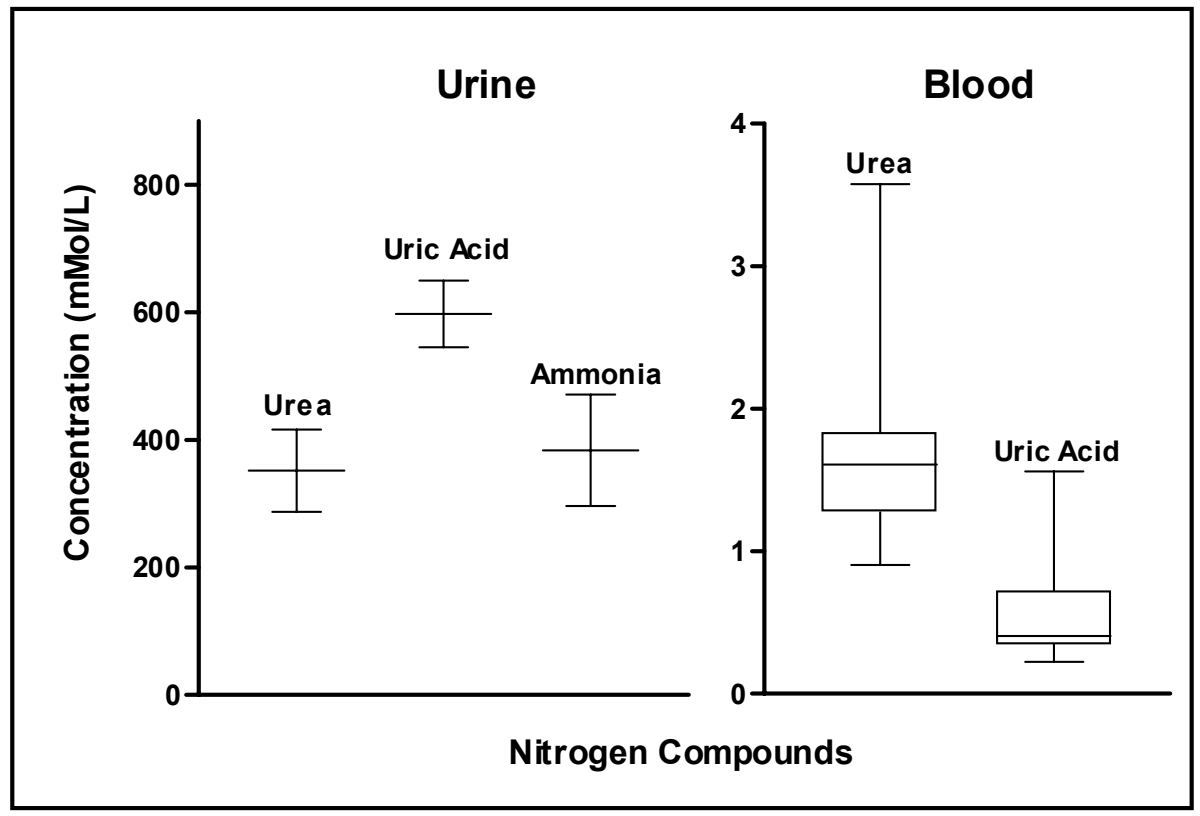

Fig. 1. Comparative levels of urine and blood urea and uric acid in native chinstrap penguin Pygoscellis antarctica. 
Pygoscellis adeliae

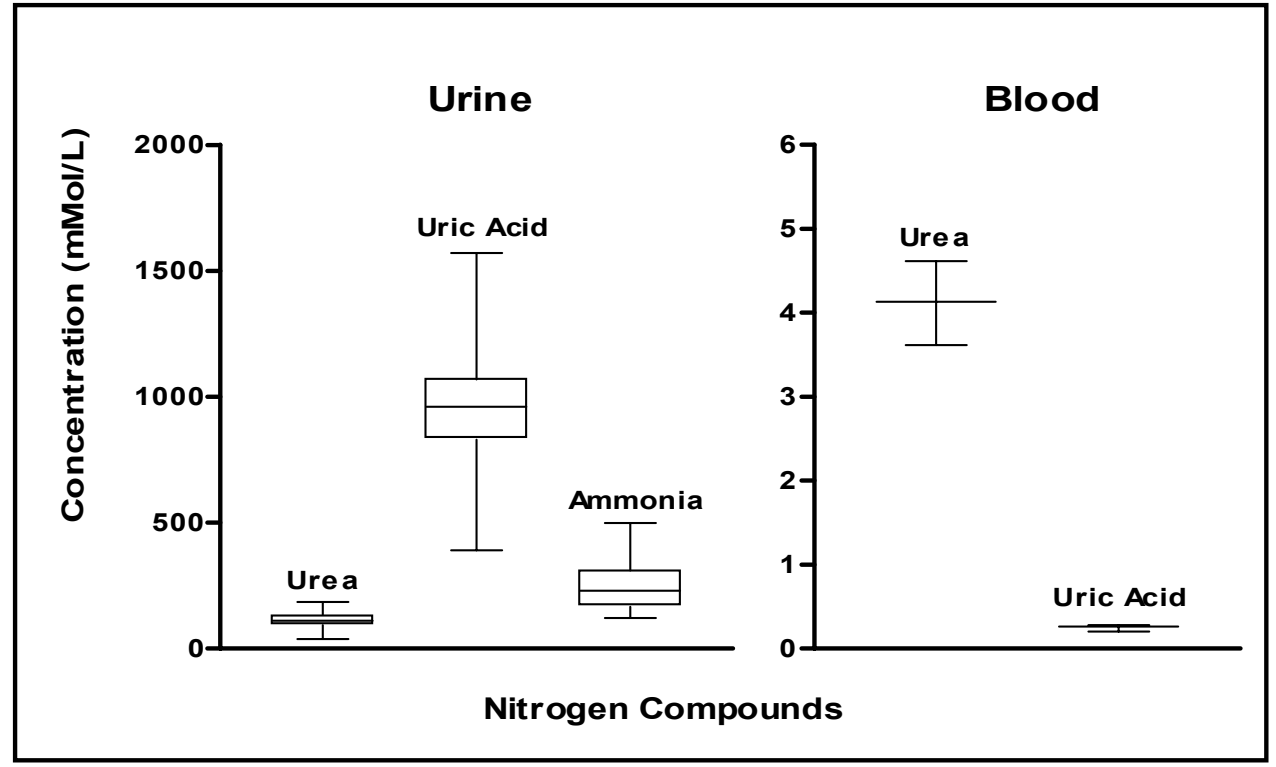

Fig. 2. Comparative levels of urine and blood urea and uric acid in native chinstrap penguin Pygoscellis adeliae.

\section{Pygoscellis papua}

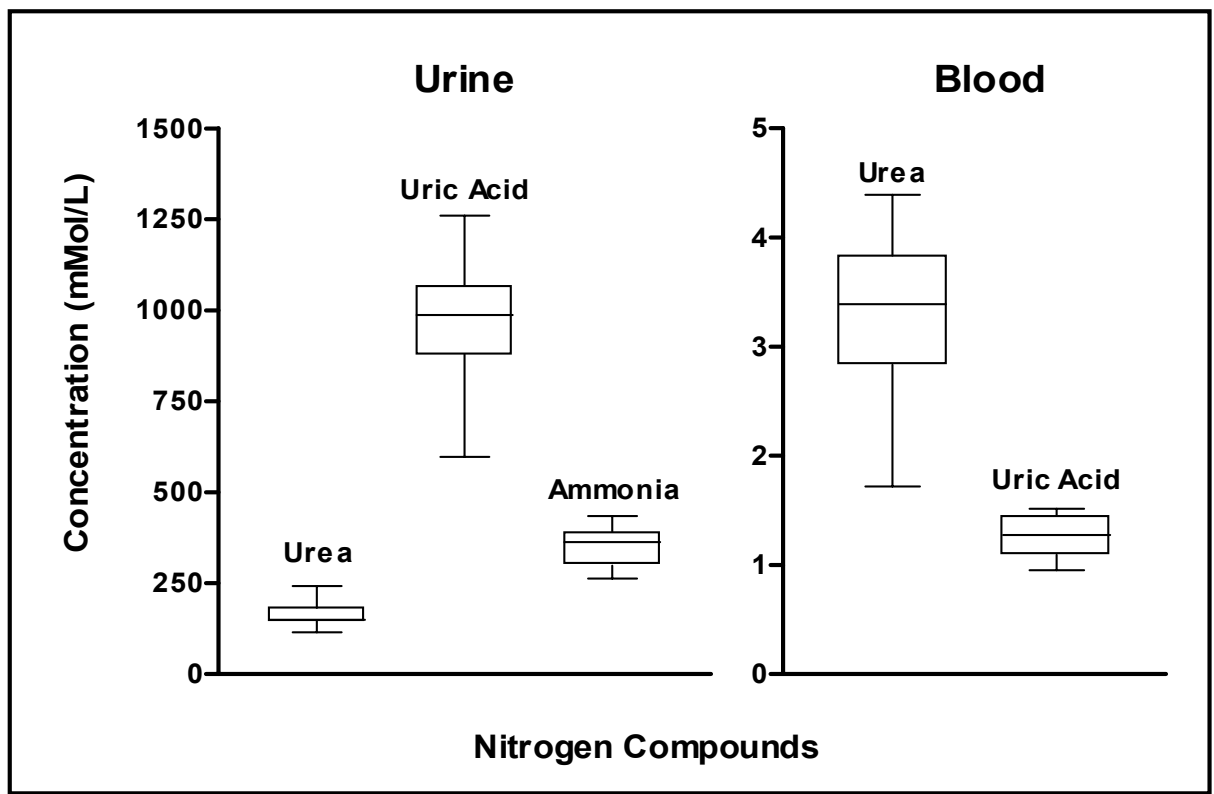

Fig. 3. Comparative levels of urine and blood urea and uric acid in native chinstrap penguin Pygoscellis papua. 


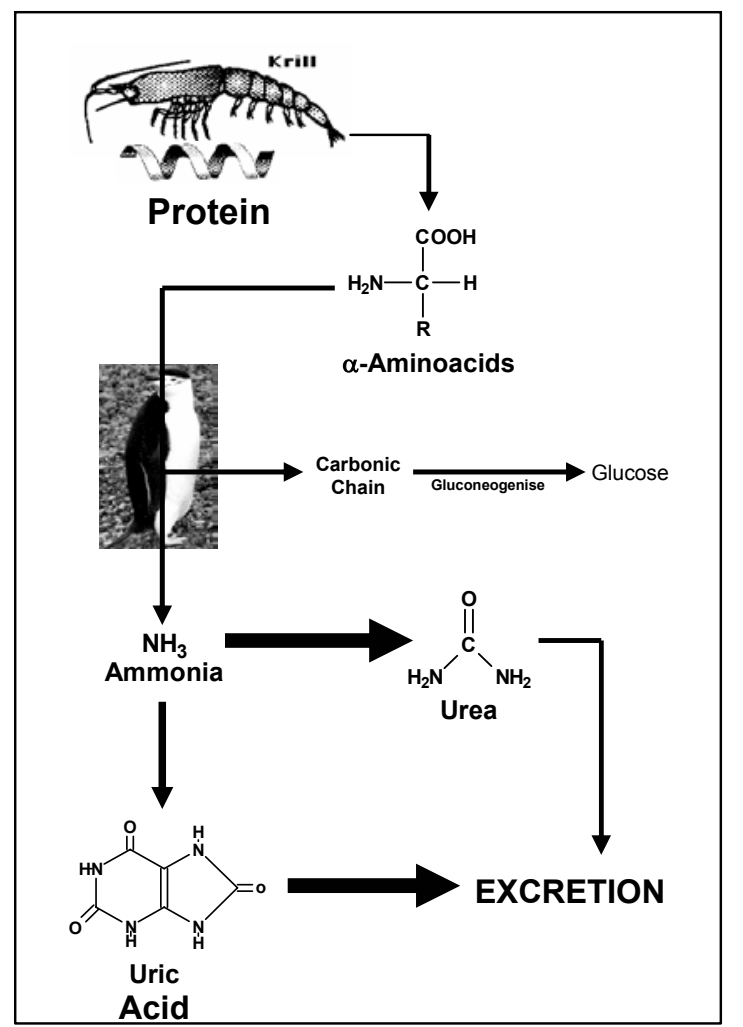

Fig. 4. Metabolic interrelations in ureogenesis and the nitrogenous excretory metabolism in penguins. Being fed in the native state by a hyperproteic diet mainly from the Krill, the high levels of blood glucose found in this animals might be a consequence of a gluconeogenesis activity starting by the oxidative deamination of aminoacids. Since the high levels of blood urea do not correspond to the urine excreted urea it is possible to suppose that part of the urea nitrogen might be recycled and used for the synthesis of uric acid.

The data on Table 1 are very clear in the sense that Pygoscellidae penguins ( $P$. antarctica, $P$. adeliae and $P$. papua), as well as other birds studied, are uricotelic animals considering that they excrete uric acid as the main final product of the nitrogen metabolism. However, the high blood urea levels displayed by those birds (Fig. 1- 3) as well as the levels of hepatic arginase (RODRIGUES et al. (1998) and the high affinity of this enzyme for arginine are evidences for the ureogenic activity of these birds. Furthermore, the fact that these birds show a high ureogenic capacity together with an uricotelic excretory profile is not yet very clear. It is possible however that this might be the result of the metabolic need to desaminate aminoacids from the high protein diet provided by the Krill and the low solubility of uric acid in the aqueous medium, as depicted in Fig. 4.

\section{REFERENCES}

BALDWIN, E. Dinamic aspects of biochemistry. Cambridge, University Press, 1947.

BERGMEYER, H.U. Methods of enzymatic analysis. 3rd ed., Vol. 9. Florida, VCH Publ., 449-453, 1985.

CARAWAY, W.T. Determination of uric acid in serum by a carbonate method. Am. J. Clin. Path. 25:840-845, 1955.

CLEMENTI, A. Sull' assenza assoluta e incondizionata dell' arginasi nel fegato degli uccelli. Boll. Soc. Ital. Biol. Sper. 22:1075-1076, 1946
CHANEY, A.L; MARBACH, P.E. Modified reagentes for determination of urea and ammonia. Clin. Chem. 8:130-132, 1962.

FERRER, M.; RODRIGUEZ, T.G.; CARRILLO, J.C.; CASTROVIEJO, J. Hematocrit and blood chemistry values in captive raptors (Gyps fulvus, Buteo buteo, Milvus migrans, Anguila heliaca). Comp. Biochem. Physiol. 87A:1123-1127, 1987.

KATUNUMA, N.; MATSUDA, Y.; KURODA, Y. Phylogenetic Aspects of Different Regulatory Mechanisms of Glutamine Metabolism. Ad. Enzy. Regul. 8:73-81,1970.

MCNABB, F.M.; MCNABB, R.A. Proportions of ammonia, urea, urate and total nitrogen in avian urine and quantitative methods for their analysis on a single urine sample. Poutry Science. 54:1498-1505, 1975.

NEEDHAM, J.; GREEN, D.E. Prespectives in Biochemistry, Cambridge, University Press, 1938.

RODRIGUES, E.; ROSA, R.; BACILA, M. Compartive aspects of the nitrogen metabolism in antarctic birds. Trends Comp. Biochem. Physiol. 2:447-463, 1996.

RODRIGUES, E.; ROSA, R.; BACILA, M. Ureogenesis in Antarctic birds - blood levels of nitrogen compounds and liver kidney arginase in penguins. Antarctic Record. 42(1):111-119, 1998.

ROSA, C.D.; ROSA, R.; RODRIGUES, E.; BACILA, M. Blood constituents and electrophoretic patterns in Antarctic birds: penguins and skuas. Comp. Biochem. Physiol. 104A:117-123, 1993. 